\title{
Blood Retention Pattern of Polycyclic Aromatic Hydrocarbons in Guinea-Pigs Treated with Crude Oil
}

\author{
Gogo Appolus Obediah ${ }^{1}$, Ibiba Felix Oruambo ${ }^{2}$ \\ ${ }^{1}$ Chemistry Department, Rivers State University of Science and Technology, Port Harcourt, Nigeria
}

\begin{abstract}
Exposures to crude oil are common among oil workers and rural populace and contribute a global health burden. The aim of this study is to investigate the blood retention patterns of polycyclic aromatic hydrocarbons (PAHs) in guinea pigs treated with bonny light crude oil (BLCO). The objective of the study was to find out if there is a peculiar pattern of retention of PAH after exposure to crude oil. Fifteen adult male guinea pigs were used for the research and separated into five groups of three animals. All animals were fed with freshly cut elephant grass daily ad libitum. Group 1 served as the control (untreated) group. Group 2-6 were treated liberally with crude oil by skin application (dorsal side of ear) once. The sacrifices were done at 1, 2, 3 and 4 hours interval. Blood samples were collected and extracted with dichloromethane (DCM) and concentrated before GC-MS analysis. The chromatogram shows 14 PAHs absorbed and retained in the blood after $1 \mathrm{hr}$ exposure. 4 out of the 14 absorbed PAHs were still retained in the blood up to $2 \mathrm{hrs}$ after skin exposure. The chromatogram for 3 \& 4 hrs show no retained PAHs but contained peaks which might be indicative of other PAHs. The results obtained from this study reveal that PAHs have a clearance time of approximately $<4$ hrs in the blood and that its metabolites may cause carcinogenesis if it forms conjugate with DNA at site critical for cell growth.
\end{abstract}

Keywords: PAHs, Crude oil, GC/MS,

\section{Introduction}

Crude oil is a complex mixture of many different components. Its exploration and transportation has generated a lot of environmental problems. It is noteworthy, that the devastating consequences of crude oil spill in the Niger Delta of Nigeria poses great hazards on both human and animals.

Since crude oil is a complex liquid, there is potential occupational exposure to a variety of substances: various hydrocarbons and other organic compounds, dissolved gases and metal compounds. Exposure is possible in all operations involving the product, including drilling, pumping and treating steps; transport by pipeline, ships or rail cars; storage and refinery processing. The primary route of exposure is through skin contact.

Polycyclic Aromatic Hydrocarbons (PAHs) are a group of chemicals that occur naturally in coal, crude oil and gasoline. Incomplete combustion of organic material results in emission of PAHs [1]. These molecules consist of two or more aromatic rings fused in linear, angular or cluster arrangements and by definition are composed of hydrogen and carbon. As pure chemicals, these compounds are colourless, white or pale yellow solids. Their physicochemical properties, vapour pressure and solubility vary according to their molecular weight. PAHs possess a highly characteristic UV absorbance spectrum although some may be fluorescent [2]. PAHs are ubiquitous and persistent as a consequence of natural (forest fires and volcanic eruptions) and human activities [3].

The main objective of this research work is to determine the blood retention pattern of PAHs in guinea-pigs treated with BLCO by skin application. And to ascertain whether or not,
PAHs exposure could serve as an indicator of genomic toxicity.

Although several works have been done in this field of research, there is limited information on the retention patterns of various PAHs in the blood.

\section{Materials and Methods}

\subsection{Test Substance}

Fresh Nigerian (Bonny) Light Crude Oil (BLCO) was obtained from the Nigerian National Petroleum Corporation (NNPC) here in Port Harcourt, Rivers State, Nigeria, and brought to the laboratory in an amber sample bottle.

\subsection{Laboratory animals}

Fifteen adult male guinea pigs (8-12 weeks old) were purchased from the animal farm at University of Port Harcourt. The animals were brought to the biochemistry animal room and were fed with freshly cut elephant grass daily ad libitum.

\subsection{Treatment of animals}

The animals used in this research work were fifteen in number. They were divided into six groups. Group 1 consisted of two animals and served as the control (untreated) group. Group 2-5 consisted of two animals each, these groups was treated with liberally with BLCO once by skin application and the blood samples were collected after 1, 2, 3, and 4hours intervals. Group 6 consisted of three animals; this group was treated daily for 10 consecutive days, after the tenth day the urine and faeces were pooled for nickel and vanadium analysis. 


\section{International Journal of Science and Research (IJSR) \\ ISSN (Online): 2319-7064}

Index Copernicus Value (2013): 6.14 | Impact Factor (2015): 6.391

\subsection{Blood collection, processing and storage}

$3 \mathrm{ml}$ of blood was taken from each research animal and was transferred into labeled heparin sample bottles. The sample bottles were placed into a covered ice container immediately after collection to protect the samples from heat and ambient light. The blood samples were then centrifuged at 10,000 rpm for 30 min on RP-1000 Centrifuge to obtain the plasma. The plasma from each sample was then separated from the whole blood and stored in tightly capped vials at $-4^{0} \mathrm{C}$ until ready for use.

\subsection{Sample preparation for PAHs assay}

The plasma samples were thawed at room temperature. PAHs were extracted from the plasma by liquid-liquid extraction using high purity Dichloromethane (DCM). The apparatus for this consisted of a $25 \mathrm{ml}$ volume separating funnel mounted on a retort stand. The separating funnel was thoroughly washed and dried over night in a muffle furnace at an elevated temperature. Prior to use the funnel was rinsed vigorously with dichloromethane for several minutes. This was removed and allowed to drain and dry completely in fume cupboard. The plasma sample (of less than $3 \mathrm{ml}$ ) was mixed with $5 \mathrm{ml}$ of dichloromethane. This was shaken vigorously for $2 \mathrm{~min}$ and allowed to separate and settle. After $10 \mathrm{~min}$, the organic layer was removed and the process was repeated with the aqueous layer twice. The three portions of the organic phase were combined and evaporated to $1 \mathrm{ml}$ volume using a rotary evaporator.

\subsection{Chromatographic instrumentation and condition}

The analysis was carried out on a Hewlet Packard Gas Chromatograph coupled to a mass spectrometer with an autosampler and a $30 \mathrm{~m} 0.33$ id DB-5 MS fused silica capillary column. Chromatographic analysis was run and interpreted with Chemstation for GC/MS for Agilent Technologies running on a Del computer with Windows NT. Helium was used as the carrier gas and the column head pressure was maintained at 10 psi to give an approximate flow rate of $1 \mathrm{ml} / \mathrm{min}$. The injector and transfer line were maintained at 290 and $250^{\circ} \mathrm{C}$, respectively. All injection volumes were $1 \mu \mathrm{l}$ in the split less mode. The column temperature was initially held at $70^{\circ} \mathrm{C}$ for $4 \mathrm{~min}$, ramped to $300^{\circ} \mathrm{C}$ at a rate of $10^{\circ} \mathrm{C} / \mathrm{min}$, and then temperature was held at $300^{\circ} \mathrm{C}$ for $10 \mathrm{~min}$. The mass spectrometer was used in electron ionization mode and all spectra were acquired using a mass range of $\mathrm{m} / \mathrm{z} 50-400$ and automatic gain control (AGC).

\section{Results}

Table 1: Estimation of PAHs in blood of untreated (controls) animals

\begin{tabular}{|c|c|c|c|c|c|}
\hline & Compound & R.T. QIon & Response & Conc Units & $\operatorname{Dev}$ (Min) \\
\hline \multicolumn{5}{|c|}{ Target Compounds } & \multirow[t]{18}{*}{ Qvalue } \\
\hline 1) & Naphthalene & 0.000 & 0 & N.D. & \\
\hline 2) & 2-Methyl Naphthalene & 0.000 & 0 & N.D. & \\
\hline 3) & Acenaphthene & 0.000 & 0 & N.D. & \\
\hline 4) & Acenaphthylene & 0.000 & 0 & N.D. & \\
\hline 5) & Fluorene & 0.000 & 0 & N.D. & \\
\hline 6) & Phenanthrene & 0.000 & 0 & N.D. & \\
\hline 7) & Anthracene & 0.000 & 0 & N.D. & \\
\hline 8) & Fluoranthene & 0.000 & 0 & N.D. & \\
\hline 9) & Pyrene & 0.000 & 0 & N.D. & \\
\hline 10) & Benz (a) anthracene & 0.000 & 0 & N.D. & \\
\hline 11) & Chrysene & 0.000 & 0 & N.D. & \\
\hline 12) & Benzo (b) fluoranthene & 0.000 & 0 & N.D. & \\
\hline 13) & Benzo (k) fluoranthene & 0.000 & 0 & N.D. & \\
\hline 14) & Benzo (a) pyrene & 0.000 & 0 & N.D. & \\
\hline 15) & Indeno $(1,2,3$-cd $)$ pyrene & 0.000 & 0 & N.D. & \\
\hline 16) & Dibenz $(a, h)$ anthracene & 0.000 & 0 & N.D. & \\
\hline 17) & Benzo $(g, h, i)$ perylene & 0.000 & 0 & N.D. & \\
\hline
\end{tabular}

$(\#)$ = qualifier out of range $(m)=$ manual integration $(+)=$ signals summed

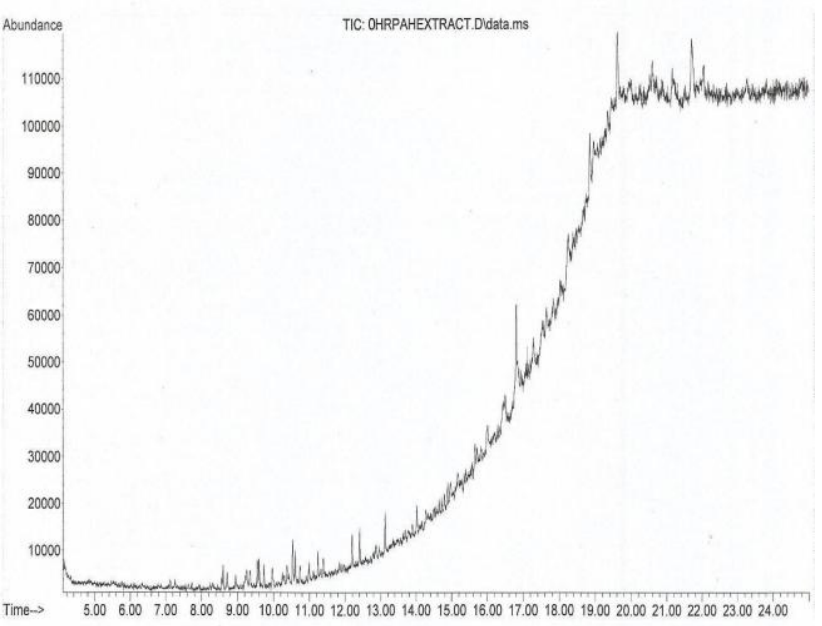

Figure 1: Chromatograph of PAHs in the blood at 0 hours.

Table 2: Estimation of PAHs in the blood after 1 hour of dermal application of crude oil

\begin{tabular}{|c|c|c|c|c|c|c|}
\hline Compound & R.T. & QIon & Response & Conc Units & Dev & (in) \\
\hline \multicolumn{5}{|l|}{ Target Compounds } & \multicolumn{2}{|c|}{ Qvalue } \\
\hline 1) Naphthalene & 4.791 & 128 & 133588 & $0.02 \mathrm{PPM}$ & $\#$ & 69 \\
\hline 2) 2-Methyl Naphthalene & 5.657 & 142 & 1043740 & $1.11 \mathrm{PPM}$ & & 94 \\
\hline 3) Acenaphthene & 7.053 & 152 & 197097 & $0.12 \mathrm{PPM}$ & $\#$ & 1 \\
\hline 4) Acenaphthylene & 7.382 & 153 & 354092 & $0.39 \mathrm{PPM}$ & & 86 \\
\hline 5) Fluorene & 8.371 & 166 & 326879 & $0.34 \mathrm{PPM}$ & $\#$ & 63 \\
\hline 6) Phenanthrene & 10.397 & 178 & 2081477 & $1.74 \mathrm{PPM}$ & \# & 90 \\
\hline 7) Anthracene & 10.476 & 178 & 394084 & $0.32 \mathrm{PPM}$ & $\#$ & 66 \\
\hline 8) Eluoranthene & 13.112 & 202 & 659854 & $0.56 \mathrm{PPM}$ & $\#$ & 94 \\
\hline 9) Pyrene & 13.627 & 202 & 599276 & $0.48 \mathrm{PPM}$ & $\#$ & 86 \\
\hline 10) Benz (a) anthracene & 16.496 & 228 & 115649 & $0.11 \mathrm{PPM}$ & $\#$ & 34 \\
\hline 11) Chrysene & 16.580 & 228 & 208449 & $0.18 \mathrm{PPM}$ & $\#$ & 2 \\
\hline 12) Benzo (b) fluoranthene & 18.911 & 252 & 47770 & $0.04 \mathrm{PPM}$ & \# & 1 \\
\hline 13) Benzo $(k)$ fluoranthene & 18.912 & 252 & 47909 & $0.02 \mathrm{PPM}$ & $\begin{array}{l}\pi \\
\#\end{array}$ & 1 \\
\hline 14) Benzo (a) pyrene & 19.814 & 252 & 71227 & $0.06 \mathrm{PPM}$ & \# & 55 \\
\hline 15) Indeno $(1,2,3-\mathrm{cd})$ pyrene & 0.000 & & 0 & N.D. & & \\
\hline 16) Dibenz $(a, h)$ anthracene & 0.000 & & 0 & N.D. & & \\
\hline 17) Benzo $(g, h, i)$ perylene & 0.000 & & 0 & N.D. & & \\
\hline
\end{tabular}

$(\#)$ = qualifier out of range $(m)=$ manual integration $(+)=$ signals summed 


\section{International Journal of Science and Research (IJSR) \\ ISSN (Online): 2319-7064 \\ Index Copernicus Value (2013): 6.14 | Impact Factor (2015): 6.391}

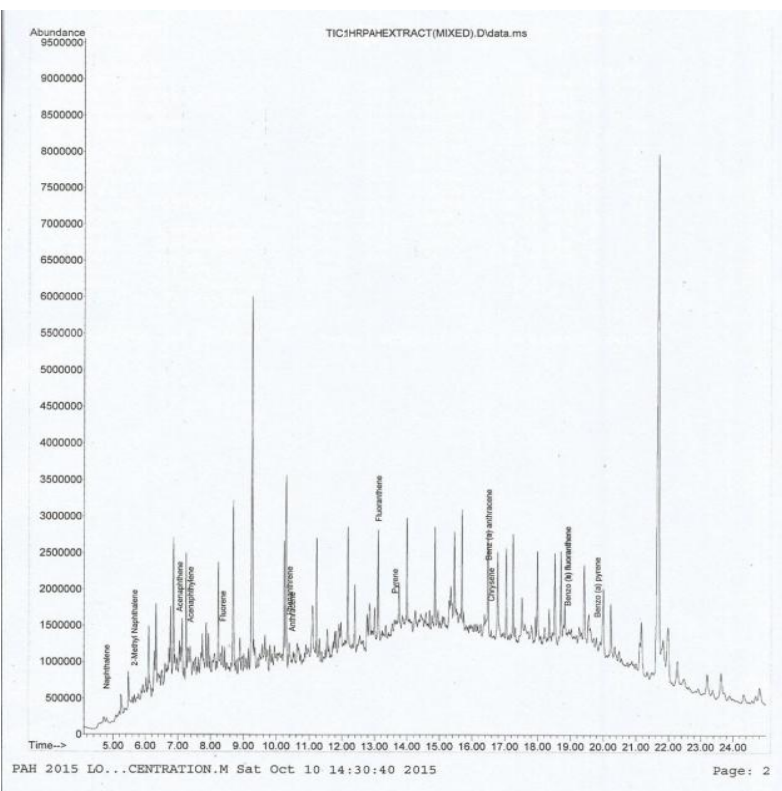

Figure 2: Chromatogram of PAHs in the blood after 1 hour of dermal application of crude oil.

Table 3: Estimation of PAHs in blood after 2 hours of dermal application of crude oil

\begin{tabular}{|c|c|c|c|c|c|c|}
\hline Compound & R.T. & QIon & Response & Conc Units & \multicolumn{2}{|c|}{$\operatorname{Dev}(\mathrm{Min})$} \\
\hline Target Compounds & & & & & Qva & \\
\hline 1) Naphthalene & 0.000 & & 0 & N.D. & & \\
\hline 2) 2-Methyl Naphthalene & 0.000 & & 0 & N.D. & & \\
\hline 3) Acenaphthene & 0.000 & & 0 & N.D. & & \\
\hline 4) Acenaphthylene & 0.000 & & 0 & N.D. & & \\
\hline 5) Fluorene & 0.000 & & 0 & N.D. & & \\
\hline 6) Phenanthrene & 10.388 & 178 & 1796080 & $1.50 \mathrm{PDM}$ & $\#$ & 76 \\
\hline 7) Anthracene & 10.479 & 178 & 743234 & $0.62 \mathrm{PPM}$ & $\#$ & 63 \\
\hline 8) Fluoranthene & 13.125 & 202 & 275347 & $0.22 \mathrm{PPM}$ & $\#$ & 60 \\
\hline 9) Pyrene & 13.636 & 202 & 192888 & 0.14 PPM & $\#$ & 58 \\
\hline 10) Benz (a) anthracene & 0.000 & & 0 & N.D. & & \\
\hline 11) Chrysene & 0.000 & & 0 & N.D. & & \\
\hline 12) Benzo (b) fluoranthene & 0.000 & & 0 & N.D. & & \\
\hline 13) Benzo ( $k$ ) fluoranthene & 0.000 & & 0 & N.D. & & \\
\hline 14) Benzo (a) pyrene & 0.000 & & 0 & N.D. & & \\
\hline 15) Indeno $(1,2,3$-cd $)$ pyrene & 0.000 & & 0 & N.D. & & \\
\hline 16) Dibenz $(a, h)$ anthracene & 0.000 & & 0 & N.D. & & \\
\hline 17) Benzo $(g, h, i)$ perylene & 0.000 & & 0 & N.D. & & \\
\hline
\end{tabular}

$(\#)$ = qualifier out of range $(\mathrm{m})=$ manual integration $(+)=$ signals sumed

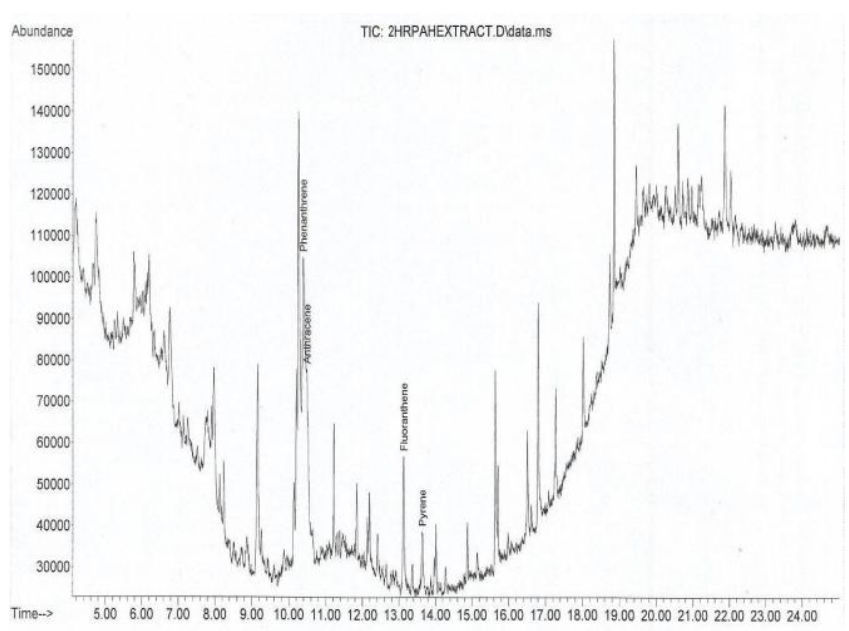

Figure 3: Chromatogram of PAHs in the blood after 2 hours of dermal application of crude oil.
Table 4: Estimation of PAHs in the blood after 3 hours of dermal application of crude oil

\begin{tabular}{|c|c|c|c|c|c|}
\hline & Compound & R.T. QIon & Response & Conc Units & $\operatorname{Dev}$ (Min) \\
\hline Targe & et Compounds & & & & Qvalue \\
\hline 1) & Naphthalene & 0.000 & 0 & N.D. & \\
\hline 2) & 2-Methyl Naphthalene & 0.000 & 0 & N.D. & \\
\hline 3) & Acenaphthene & 0.000 & 0 & N.D. & \\
\hline 4) & Acenaphthylene & 0.000 & 0 & N.D. & \\
\hline 5) & Fluorene & 0.000 & 0 & N.D. & \\
\hline 6) & Phenanthrene & 0.000 & 0 & N.D. & \\
\hline 7) & Anthracene & 0.000 & 0 & N.D. & \\
\hline 8) & Fluoranthene & 0.000 & 0 & N.D. & \\
\hline 9) & Pyrene & 0.000 & 0 & N.D. & \\
\hline 10) & Benz (a) anthracene & 0.000 & 0 & N.D. & \\
\hline 11) & Chrysene & 0.000 & 0 & N.D. & \\
\hline 12) & Benzo (b) fluoranthene & 0.000 & 0 & N.D. & \\
\hline 13) & Benzo (k) fluoranthene & 0.000 & 0 & N.D. & \\
\hline 14) & Benzo (a) pyrene & 0.000 & 0 & N.D. & \\
\hline 15) & Indeno $(1,2,3-c d)$ pyrene & 0.000 & 0 & N.D. & \\
\hline 16) & Dibenz $(a, h)$ anthracene & 0.000 & 0 & N.D. & \\
\hline 17) & Benzo $(g, h, i)$ perylene & 0.000 & 0 & N.D. & \\
\hline
\end{tabular}

$(\#)=$ qualifier out of range $(m)=$ manual integration $(+)=$ signals summed

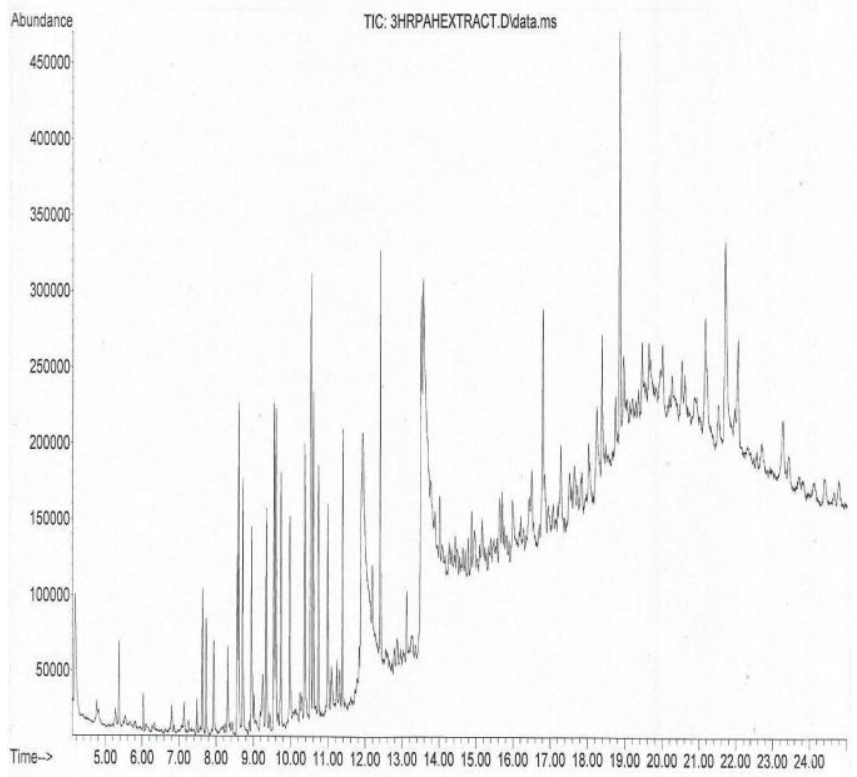

Figure 4: Chromatograph of PAHs in the blood after 3 hours of dermal application of crude oil.

Table 5: Table of estimation of PAHs in the blood after 4 hours of dermal application of crude oil

\begin{tabular}{|c|c|c|c|c|c|}
\hline & Compound & R.I. QIon & Response & Conc Units & $\operatorname{Dev}(\operatorname{Min})$ \\
\hline \multicolumn{5}{|c|}{ Target Compounds } & \multirow[t]{18}{*}{ Qvalue } \\
\hline 1) 1 & Naphthalene & 0.000 & 0 & N.D. & \\
\hline 2) 2 & 2-Methyl Naphthalene & 0.000 & 0 & N.D. & \\
\hline 3) $\mathrm{F}$ & Acenaphthene & 0.000 & 0 & $\mathbb{N} . \mathbb{D}$. & \\
\hline 4) $\mathrm{F}$ & Acenaphthylene & 0.000 & 0 & N.D. & \\
\hline 5) & Fluorene & 0.000 & 0 & N.D. & \\
\hline 6) & Phenanthrene & 0.000 & 0 & N.D. & \\
\hline 7) $\mathrm{F}$ & Anthracene & 0.000 & 0 & N.D. & \\
\hline 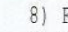 & Fluoranthene & 0.000 & 0 & N.D. & \\
\hline 9) $B$ & Pyrene & 0.000 & 0 & N.D. & \\
\hline 10) $B$ & Benz (a) anthracene & 0.000 & 0 & N.D. & \\
\hline 11) $\mathrm{c}$ & Chrysene & 0.000 & 0 & N.D. & \\
\hline 12) $\mathrm{B}$ & Benzo (b) fluoranthene & 0.000 & 0 & N.D. & \\
\hline 13) $\mathrm{B}$ & Benzo ( $\mathrm{k}$ ) fluoranthene & 0.000 & 0 & N.D. & \\
\hline 14) $\mathrm{B}$ & Benzo (a) pyrene & 0.000 & 0 & N.D. & \\
\hline 15) 1 & Indeno $(1,2,3-c d)$ pyrene & 0.000 & 0 & N.D. & \\
\hline 16) $\mathrm{D}$ & Dibenz $(\mathrm{a}, \mathrm{h})$ anthracene & 0.000 & 0 & N.D. & \\
\hline 17) $\mathrm{B}$ & Benzo $(g, h, i)$ perylene & 0.000 & 0 & N.D. & \\
\hline
\end{tabular}

$(\#)=$ qualifier out of range $(\mathrm{m})=$ manual integration $(t)=$ signals summed 


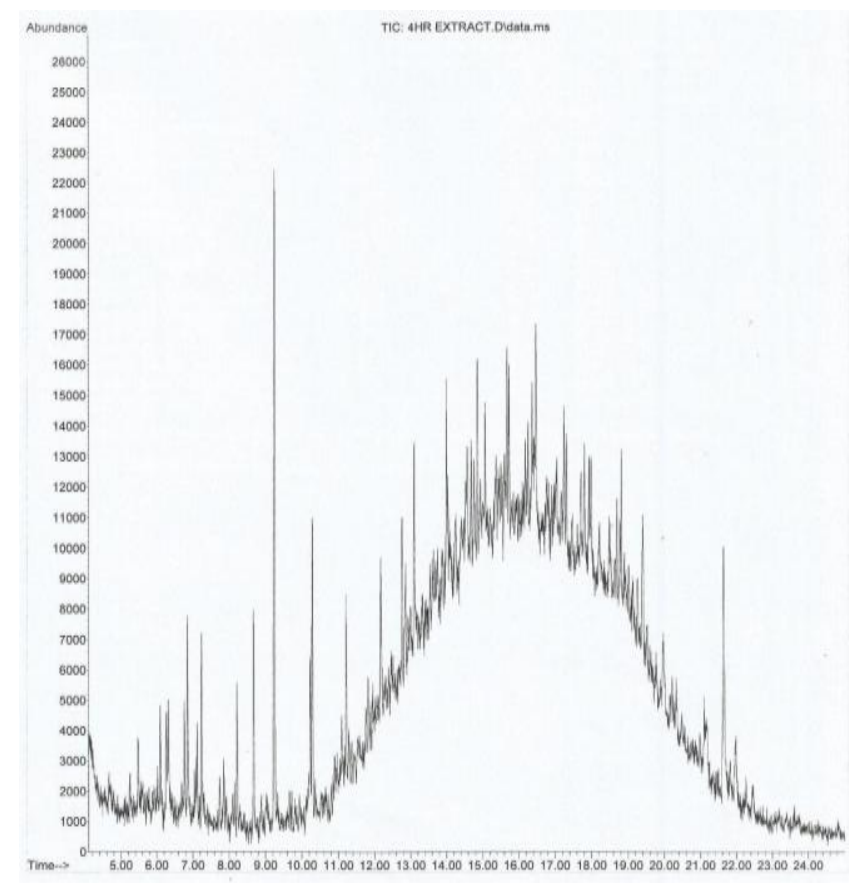

Figure 5: Chromatogram of PAHs in the blood after 4 hours of dermal application of crude oil.

\section{Discussion}

The chromatogram results show the appearance of $\mathrm{PAH}$ peaks, the source of which is the crude oil as the PAH peaks were not seen in the control (untreated) group (table 1 and figure 1). The results also show that 14 PAHs were retained in the blood after one hour of exposure (table 2 \&figure 2). These 14 PAHs are: acenaphthene, acenaphthylene, anthracene, benz[a]anthracene, benzo[b]fluoranthene, benzo[k]fluoranthene, benzo[a]pyrene, chrysene, fluoranthene, fluorene, 2-methyl naphthalene, naphthalene, phenanthrene and pyrene. Table 3 and figure 3 shows that only 4 out of the 14 detected and absorbed PAHs were retained in the blood after two hours of exposure. These 4 PAHs are phenanthrene, anthracene, fluoranthene and pyrene. The 3 and 4 hours exposure analysis show no PAH retained (table 4\&5, figure 4\&5). This implies that $10 \mathrm{PAHs}$ have a retention time of less than two hours ( $<2 \mathrm{hrs})$ and 4 PAHs have retention time of less than three hours ( $<3 \mathrm{hrs})$ in the blood. It was also observed that the concentration of anthracene was on a continual increase as opposed to the concentration of other PAHs after one hour of exposure. This might be as a result of differential diffusion, metabolic pathway of the research animals and other factors

Table 4 and 5 shows no retained PAHs, but figure 5 and 6 shows peaks which might be indicative of other PAHs that the instrument (GC-MS) could not identify because the instrument have no library for them..

Differential diffusion of PAHs through the intercellular spaces is considered to be the major pathway for dermal absorption into the blood stream because of the varying concentration of individual PAHs in the blood at various time intervals (table 1, 2 \&3). This is in agreement with work done by Lenka Kotingová [4]

\section{Conclusion}

Differential diffusion of PAHs through the intercellular spaces is considered to be the major pathway for dermal absorption into the blood stream. PAHs have a varying retention pattern/time in the blood and in general have a retention time of less than four hours $(<4 \mathrm{hrs})$ in the blood.

\section{References}

[1] Agency for Toxic Substances and Disease Registry (1996). ToxFAQs ${ }^{\mathrm{TM}}$ for Polycyclic Aromatic Hydrocarbons (PAHs), In: Agency for Toxic Substances and Disease Registry, 16.01.2011, Available from http://www.atsdr.cdc.gov/toxfaqs/tf.asp?id=121\&tid=2 $\underline{5}$

[2] Fetzer, J. C. \& Biggs, W. R. (1994). A Review of the Large Polycyclic Aromatic Hydrocarbons. Polycyclic aromatic compounds, Vol. 4, No.1, pp. 3 - 17, 10406638 March 18, 2011

[3] Jongeneelen, F. J. (2001). Benchmark guideline for urinary 1-hydroxypyrene as biomarker of occupational exposure to polycyclic aromatic hydrocarbons. Annals of Occupational Hygiene, Vol. 45, No.1, (Jan), pp. 313, 0003-4878 (Print)

[4] Lenka Kotingová, (2014). Transdermal Absorption of Polycyclic Aromatic Hydrocarbons. Available from https://www.lfhk.cuni.cz/Studenti/Doktorske-studium(Ph-D-)/Konference-studentu-DSP/Archiv-konferencistudentu-DSP/FC-DSP-Abstracts-2014.aspx/ 